\title{
NPR1-Independent Activation of Immediate Early Salicylic Acid-Responsive Genes in Arabidopsis
}

\author{
Carolina Uquillas, Ingrid Letelier, Francisca Blanco, Xavier Jordana, and Loreto Holuigue \\ Departamento de Genética Molecular y Microbiología, Facultad de Ciencias Biológicas, Pontificia Universidad Católica \\ de Chile, P.O. Box 114-D, Santiago, Chile
}

Submitted 25 June 2003. Accepted 30 August 2003.

\begin{abstract}
Salicylic acid (SA) is a key signal for the activation of defense genes in response to stress. The activation of late defense genes by $\mathrm{SA}$, such as $P R-1$, involves the participation of the NPR1 protein. This protein acts as coactivator of the TGA factors that recognize as-1-like elements in the $P R-1$ promoter. Considering that functional as-1-like elements are also found in the promoter of SA- and auxin-responsive immediate early genes, we tested the hypothesis that NPR1 is also required for activation of these genes. The expression of the immediate early genes glutathione $S$ transferase (GST6) and glucosyltransferase (EIGT) was studied in nprl mutant and wild-type Arabidopsis plants. In the npr1 mutant background, SA and 2,4-dichlorophenoxyacetic acid were unable to promote transcription of $P R$ 1 but effectively stimulated the expression of GST6 and EIGT. Furthermore, increased binding of proteins to the GST6 as-1-like promoter element was detected in nuclear extracts from npr1 and wild-type plants after treatment with SA. In summary, these results indicate that activation of immediate early genes by $\mathrm{SA}$ proceeds through an NPR1-independent pathway. Therefore, we propose that activation by SA of immediate early and late genes occur by different mechanisms.
\end{abstract}

Salicylic acid (SA) plays an important role in the onset of defense reactions against environmental stressors in plants (Alvarez 2000; Borsani et al. 2001; Delaney et al. 1994; Rao and Davis 1999). The rise in SA levels triggers the activation of a number of defense genes (Maleck et al. 2000; Schenk et al. 2000). Among these genes, the best characterized code either for proteins with antimicrobial activity, such as pathogenesis-related (PR) proteins (Van Loon and Van Strien 1999) or for detoxifying enzymes, such as glutathione $S$-transferases (GST) and glucosyltransferases (GT). These enzymes play an important role in cell protection against oxidative stress (Edwards et al. 2000; Li et al. 2001). GST and GT are encoded by multigene families that are activated by pathogen infection (Alvarez et al. 1998; Horvath et al. 1998; Levine 1994; Pontier et al. 2001), different xenobiotics, and cellular stress-related agents, including SA, auxins, and $\mathrm{H}_{2} \mathrm{O}_{2}$ (Horvath and Chua 1996; Marrs 1996; Xiang et al. 1996).

Kinetic studies done in tobacco revealed the existence of two different groups of genes activated by SA, i.e., late and immediate early genes. Late genes such as $P R-1$ are activated after several hours of treatment with SA, through a process dependent on de novo protein synthesis (Qin et al. 1994; Uknes

Corresponding author: L. Holuigue; Telephone: (56-2) 686 2663; Fax: (56-2) 222 5515. E-mail: lholuig@genes.bio.puc.cl et al. 1993), and immediate early genes such as GST1 (GNT35) (Xiang et al. 1996) and IEGT (immediate early-induced glucosyltransferase) (Horvath and Chua 1996) are activated after 30 min of treatment with SA or xenobiotics. Consistent with an immediate early response, the activation of IEGT by SA does not require de novo protein synthesis (Horvath and Chua 1996; Horvath et al. 1998).

Despite the difference in activation kinetics, a common SA-responsive element, named activation sequence-1 (as-1), has been found to function in the promoter of both $P R-1 a$ (Strompen et al. 1998) and GST1 tobacco genes (Droog et al. 1995). Involvement of as-1-like elements in the SA-induced activation of late and immediate early genes in species other than tobacco has also been described. This is the case of $P R$ 1 (Lebel et al. 1998) and GST6 in Arabidopsis (Chen and Singh 1999; Chen et al. 1996). The involvement of as-1-like elements in positive and negative regulation of the $P R-1$ gene by SA in Arabidopsis is further supported by the results of functional analysis of the $P R-1$ gene by linker-scanning mutagenesis (Lebel et al. 1998).

$a s-1$ is characterized by two imperfect TGACGTCA palindromic motifs that bind bZIP transcription factors of the plant TGA family (Krawczyk et al. 2002; Lam and Lam 1995; Xiang et al. 1997). The interaction between $a s$-1-like elements and TGA factors is crucial to the regulation of $P R$ and GST genes (Fan and Dong 2002; Johnson et al. 2001a; Niggeweg et al. 2000a; Pontier et al. 2001). This was mainly demonstrated using dominant negative mutants of TGA factors in tobacco (Niggeweg et al. 2000a; Pontier et al. 2001).

The interaction between $a s$-1-like elements and TGA factors in the activation of late genes involves a novel protein named NPR1. In fact, Arabidopsis mutants in the NPR1 protein (nprl) are incapable of expressing the $P R$ genes $(P R-1, P R-2$, and $P R$ 5 ) and fail to develop pathogen resistance in response to SA or active analogs of SA (Cao et al. 1994). In addition, recent evidence supports the idea that the interaction of NPR1 with Arabidopsis TGA2 is promoted by SA and is essential for $P R-1$ gene activation (Després et al. 2000; Fan and Dong 2002; Kinkema et al. 2000; Subramaniam et al. 2001).

Consistent with a role as a TGA factor coactivator, NPR1 has been shown to interact in vitro and in vivo with different members of the TGA family. This interaction has been documented for transcription factors from Arabidopsis, tobacco, tomato, and rice (Chern et al. 2001; Després et al. 2000; Fan and Dong 2002; Niggeweg et al. 2000b; Subramaniam et al. 2001; Zhang et al. 1999; Zhou et al. 2000). NPR1 has an ankyrin repeat domain suited for protein-protein interactions (Cao et al. 1997; Ryals et al. 1997) such as those reported above.

At present, it is not known if NPR1 participates in the activation of immediate early genes. This seems a reasonable 
possibility, since the activation of early genes, like that of late genes, involves the participation of both TGA factors (Johnson et al. 2001a; Niggeweg et al. 2000a; Pontier et al. 2001) and as-1-like elements (Chen and Singh 1999; Droog et al. 1995; Ulmasov et al. 1994).

Thus, in this paper, we evaluated whether, in Arabidopsis, the NPR1 protein is required for the activation of the immediate early genes glutathione $S$-transferase (GST6) and glucosyltransferase $(E I G T)$ by SA and 2,4-dichlorophenoxyacetic acid (2,4-D), using nprl mutant plants. Results provide substantial evidence for the existence of different pathways in the activation of late and early genes by SA in Arabidopsis. While activation of $P R I-$ a well-characterized late geneproceeds through a NPR1-dependent pathway that is not activated by xenobiotics such as 2,4-D, activation of GST6 and IEGT - two genes characterized here as early genes-proceeds through a NPR1-independent pathway that is also activated by $2,4-\mathrm{D}$.

\section{RESULTS}

To study the role of NPR1 in the activation of immediate early genes by SA, we selected GST6 and IEGT. GST6 (AT2g47730) is a member of the gene family coding for GST in Arabidopsis, in which a functional SA- and auxin-responsive as-1-like promoter element have been identified (Chen and Singh 1999). IEGT (AT4g34138; UGT73B3 according to Lim et al. 2002) was selected among Arabidopsis $G T$ genes for its similarity with tobacco IEGT (Horvath and Chua 1996). An as-1-like element has been identified in the tobacco IEGT gene, which could explain its induction by SA and other xenobiotics (Horvath et al. 1998). An inspection of the putative promoter sequence of the Arabidopsis IEGT also shows the presence of an as-1-like element in position -529 to -509 from the ATG, although its role in expression remains to be elucidated. PR-1 (AT2g14610), a late gene responsive to SA, was selected as a positive control for NPR1-dependent activation.

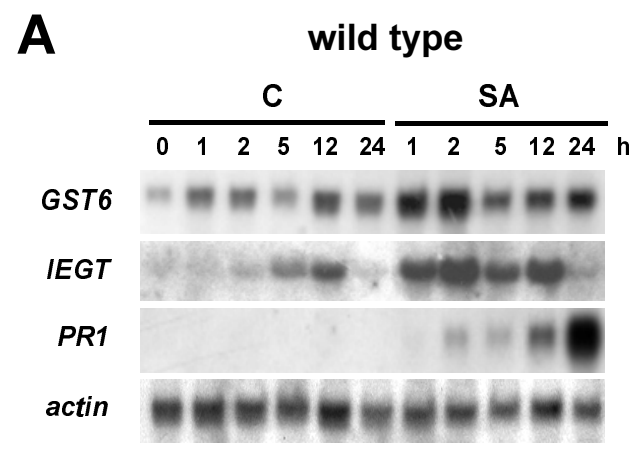

C
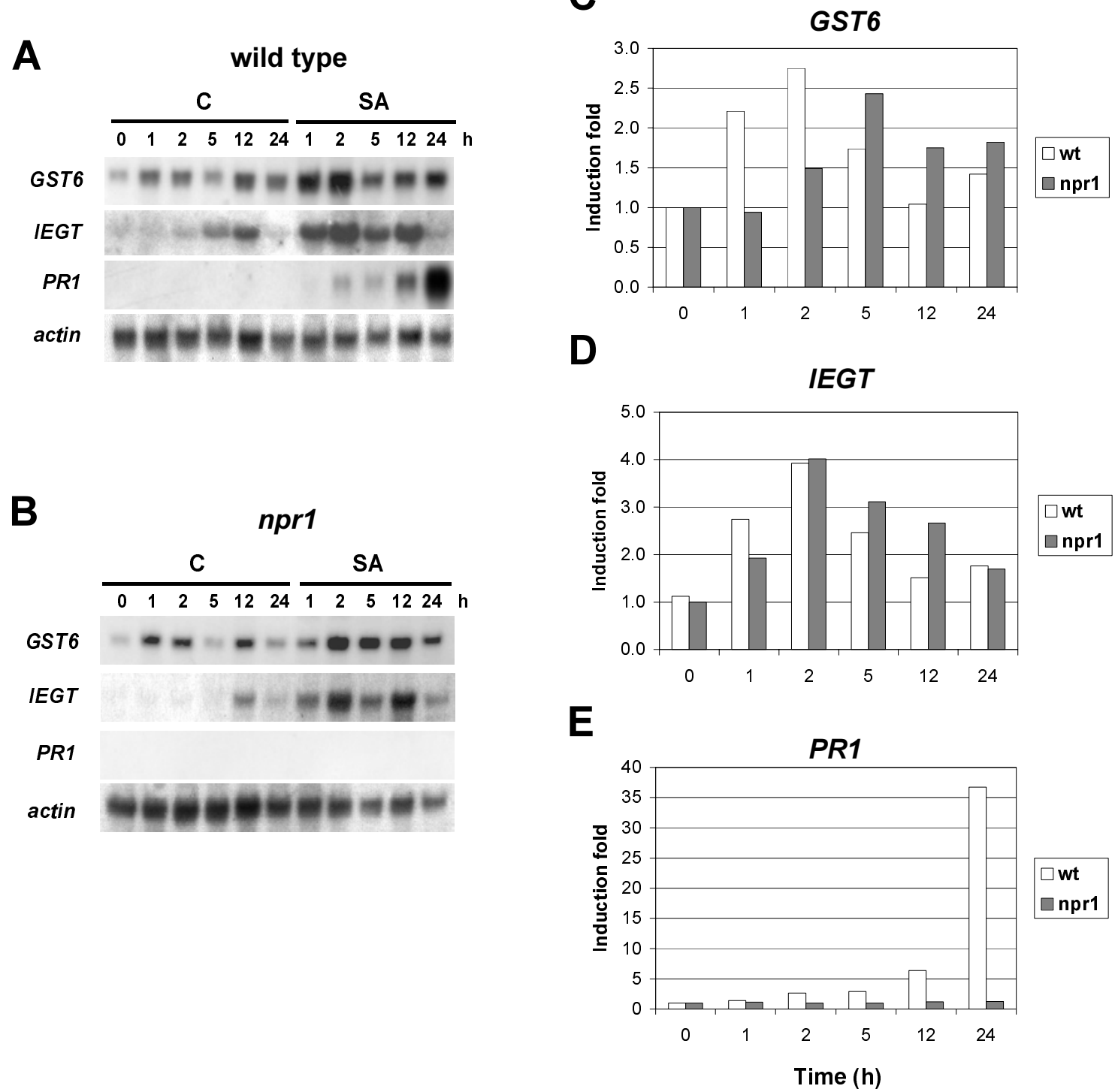

Fig. 1. Time course of expression of salicylic acid (SA)-activated genes in wild-type and nprl mutant Arabidopsis plants. A, Wild-type and B, nprl mutant Arabidopsis seedlings were treated with $\mathrm{H}_{2} \mathrm{O}(\mathrm{C})$ or $0.5 \mathrm{mM} \mathrm{SA}$ (SA) for the indicated periods (in hours). RNA blots (20 $\mu \mathrm{g}$ total RNA per lane) were sequentially hybridized with ${ }^{32} \mathrm{P}$-labeled probes for GST6, IEGT, PR1, and actin genes. C, through E, Comparison of the induction levels of GST6, $I E G T$, and $P R-1$ genes by SA in wild-type and nprl plants. Induction levels were calculated as follows. The mRNA level at each timepoint was quantified with a PhosphorImager and was calibrated with the corresponding loading control of actin mRNA. Then, the values from SA-treated samples were divided by the values of their corresponding control samples treated in the absence of SA. Data presented correspond to one representative experiment. This experiment was repeated at least three times and similar induction patterns were detected. 
Time courses of activation of GST6, IEGT, and $P R-1$ genes were analyzed in wild-type Arabidopsis seedlings treated with $0.5 \mathrm{mM}$ SA for different periods. Control treatments were performed in the absence of SA. The mRNA levels of these genes were detected by Northern blot analysis (Fig. 1A) and were quantified with a phosphorImager (Fig. 1C, D, and E, white bars). Activation of GST6 and IEGT genes by SA was detected after $1 \mathrm{~h}$ of treatment with SA and reached its peak value at $2 \mathrm{~h}$ (Fig. 1A, C, and D, white bars). In contrast, $P R-1$ gene activation reached its peak value after $24 \mathrm{~h}$ of treatment (Fig. 1A and $\mathrm{E}$, white bars). These results are consistent with the idea that both GST6 and IEGT are early activated by SA, whereas $P R-1$ belongs to the late-activated genes.

To assess whether the NPR1 protein is required for GST6 and IEGT gene activation by SA, Arabidopsis nprl mutant seedlings were subjected to the same treatments. Results, shown in Figure 1B, indicate that, in nprl plants, GST6 and IEGT genes were activated by SA to levels similar to those seen in wild-type plants (Fig. 1A and B). In addition, the activation kinetics of these genes in the nprl mutant plants was similar to that in wild-type plants (Fig. 1C and D, compare white and gray bars). As expected, SA did not activate the $P R$ 1 gene in nprl seedlings (Fig. 1B and E). These results indicate that the NPR1 protein is not required for the activation of GST6 and IEGT by SA.

To further investigate the mechanism of the immediate early response of GST6 and IEGT to SA and to test whether it occurs without requiring de novo protein synthesis, we analyzed the expression of both genes in the presence of cycloheximide (CHX), a protein synthesis inhibitor. Wild-type and nprl Arabidopsis seedlings were pretreated for $1 \mathrm{~h}$ with or without CHX $(20 \mu \mathrm{g} / \mathrm{ml})$, and then, were treated for 2 or $24 \mathrm{~h}$ with or without SA $(0.5 \mathrm{mM})$. After these treatments, the steady state levels of GST6, IEGT, and PR-1 mRNAs were quantified.

As previously shown in Figure 1, treatment of wild-type and $n p r l$ plants with SA for $2 \mathrm{~h}$ increased 2.4- to 4.8 -fold the
A

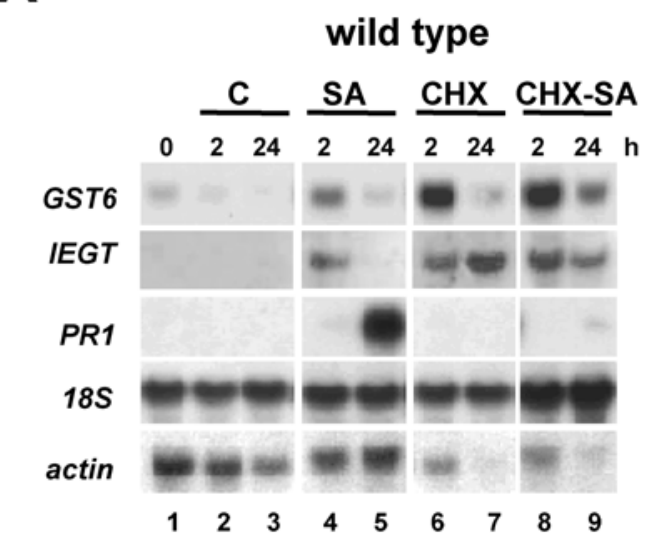

B

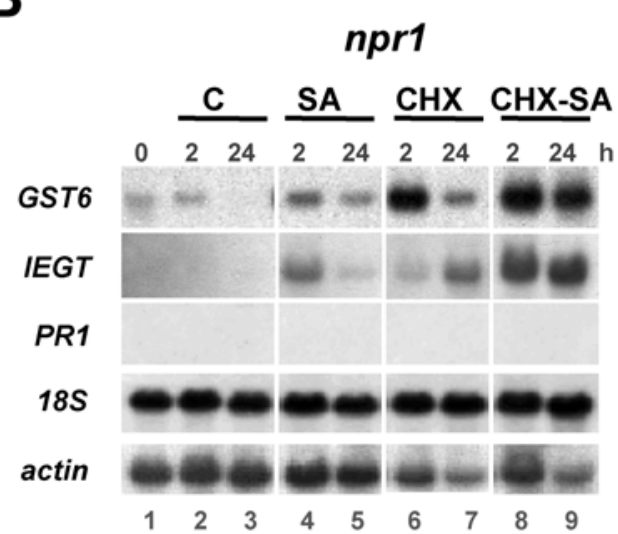

C

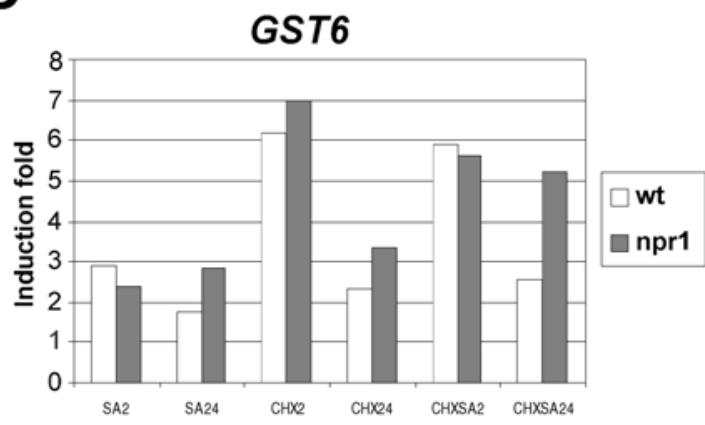

D

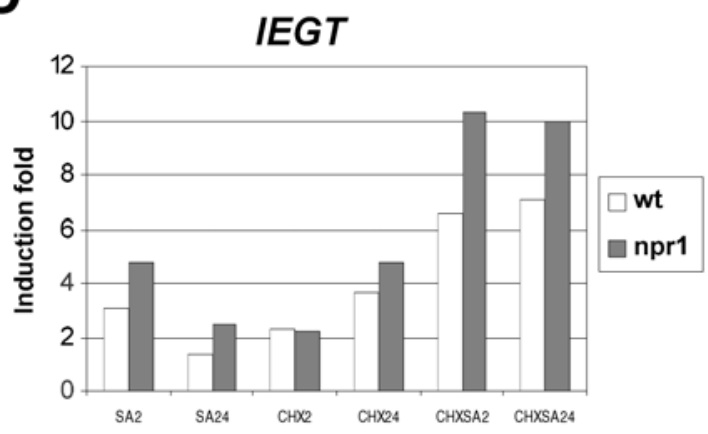

E

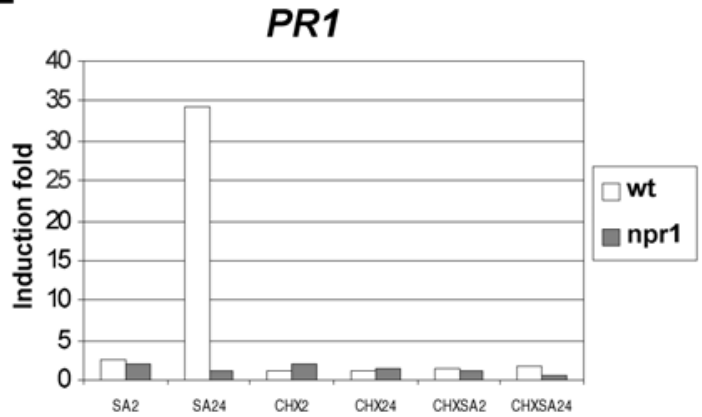

Fig. 2. Effect of cycloheximide (CHX) on the expression of salicylic acid (SA)-activated genes in wild-type and npr1 mutant Arabidopsis plants. A, Wildtype and $\mathbf{B}$, nprl mutant Arabidopsis seedlings were pretreated for $1 \mathrm{~h}$ with $\mathrm{H}_{2} \mathrm{O}$ (lanes 2 to 5) or $20 \mu \mathrm{g}$ of $\mathrm{CHX}$ per ml (lanes 6 to 9), and then, were treated for the indicated periods in the absence (lanes 2 to 3 and 6 to 7 ) or presence of $0.5 \mathrm{mM} \mathrm{SA}$ (lanes 4 to 5 and 8 to 9). Nontreated control is shown in lane 1 . RNA blots $\left(20 \mu \mathrm{g}\right.$ of total RNA per lane) were sequentially hybridized with ${ }^{32} \mathrm{P}$-labeled probes for GST6, IEGT, PR1, actin, and $18 \mathrm{~S}$ rRNA genes. $\mathbf{C}$, through E, Comparison of the induction levels of GST6, IEGT, and PR-1 genes in wild-type and nprl plants. Induction levels were calculated as follows. The mRNA level at each timepoint was quantified with a PhosphorImager and was calibrated with the corresponding loading control of $18 \mathrm{~S}$ rRNA. Then, the values from SA-treated samples were divided by the values of their corresponding control samples treated in the absence of SA. Surprisingly, treatment with CHX decreased the actin mRNA levels in plants treated for $24 \mathrm{~h}$ with SA (lanes 7 and 9 ). Data presented correspond to one representative experiment. This experiment was repeated at least three times and similar induction patterns were detected. 
GST6 and IEGT mRNAs levels (Fig. 2A and B [lanes 2 and 4], C, and D). In contrast, SA only increased the $P R-1$ mRNA level (34-fold) after $24 \mathrm{~h}$ of treatment in wild-type but not in nprl plants (Fig. 2A and B [lanes 3 and 5] and E). Treatment with CHX had different effects in the mRNA steady state levels of GST6, IEGT, and PR-1 genes. CHX alone for $2 \mathrm{~h}$ increased GST6 mRNA to levels higher than those reached after $2 \mathrm{~h}$ of treatment with SA. The effect of CHX was not sustained nor further potentiated by cotreatment with SA (Fig. 2A and B [lanes 6 to 9] and C). In contrast, treatment with $\mathrm{CHX}$ alone for $24 \mathrm{~h}$ increased IEGT mRNA to levels similar to those seen after treatment with SA for $2 \mathrm{~h}$ (Fig. 2A and B [lane 4 compared with lane 7] and D). Treatment with both $\mathrm{CHX}$ and SA produced further increases in IEGT mRNA levels after 2 and $24 \mathrm{~h}$ of treatment (Fig. 2A and B [lanes 8 and 9] and D). Unlike GST6, IEGT mRNA levels remained elevated after $\mathrm{CHX}$ treatment. As reported (Qin et al. 1994), we detected no activation of $P R-1$ gene in the presence of CHX, either alone or together with SA (Fig. 2A and B [lanes 6 through 9] and E).
The fact that CHX did not block the activation of GST6 and IEGT indicates that this process does not require de novo protein synthesis. These results are consistent with the idea that - unlike PRI-GST6 and IEGT form part of the immediate early response of plants to SA. Although GST6 and IEGT are early-activated by SA and sensitive to $\mathrm{CHX}$ treatment, the observed differences in the response to CHX (Fig. 2C and D) suggest that GST6 and IEGT mRNA levels are differentially regulated.

To determine if NPR1 plays a role in the activation of immediate early genes by compounds other than SA, we studied the activation of GST6 and IEGT by the synthetic auxin 2,4-D. We chose this compound because it has been shown to activate GST6 (Chen and Singh 1999; Chen et al. 1996). We evaluated the effect of 2,4-D on the expression of GST6, IEGT, and PR-1 in wild-type and nprl Arabidopsis plants.

In wild-type plants, 2,4-D increased the mRNA levels of both GST6 and IEGT (Fig. 3A, C, and D, white bars). This activation reached its peak value between 5 and $12 \mathrm{~h}$ of treatment. The mRNA levels remained elevated after $24 \mathrm{~h}$ of treat-
A

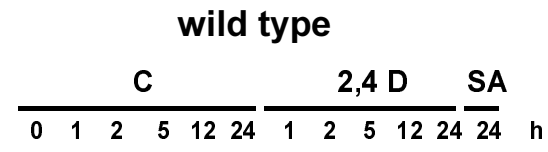

GST6

IEGT

PR1

actin

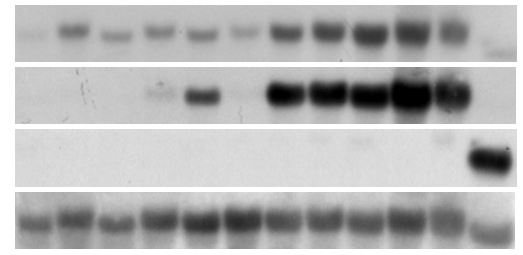

B

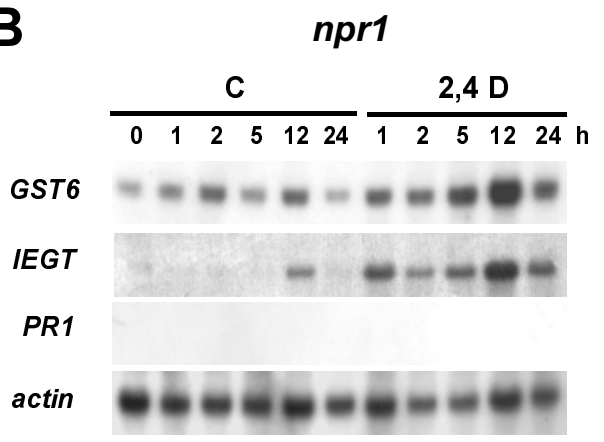

C

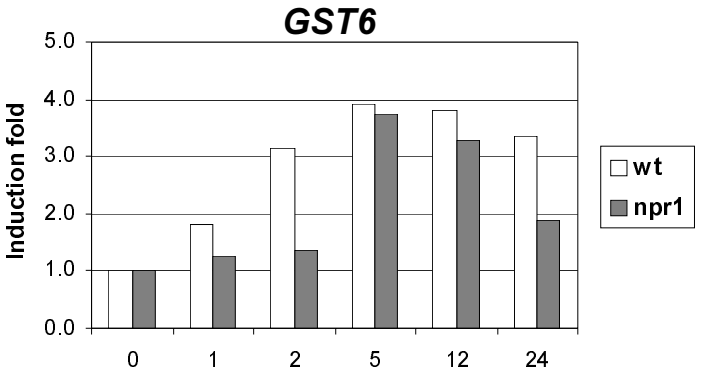

D

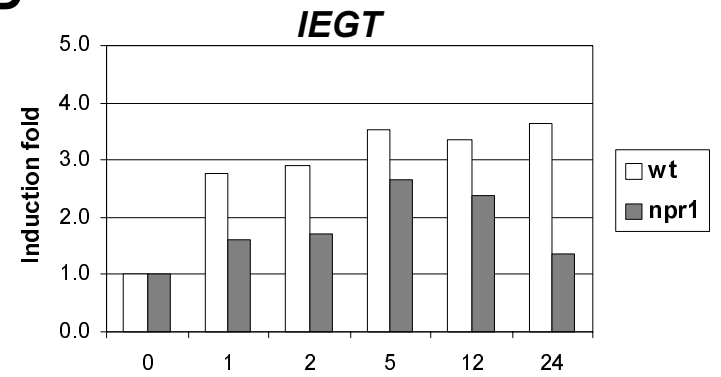

$\mathbf{E}$

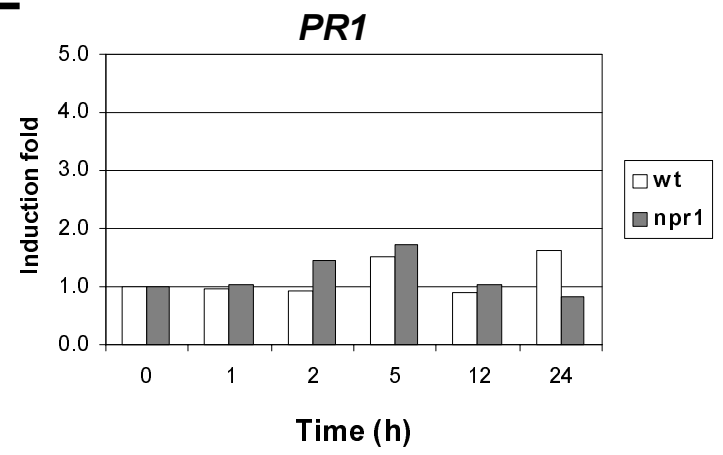

Fig. 3. Time course for expression of 2,4-dichlorophenoxyacetic acid (2,4-D)-activated genes in wild-type and nprl mutant Arabidopsis plants. A, Wildtype and B, nprl mutant Arabidopsis seedlings were treated with dimethyl sulfoxide (C) or $100 \mu \mathrm{M} 2,4-\mathrm{D}(2,4 \mathrm{D})$ for the indicated periods (in hours). A control sample treated with $0.5 \mathrm{mM}$ salicylic acid (SA) for $24 \mathrm{~h}$ was included. RNA blots (20 $\mu \mathrm{g}$ of total RNA per lane) were sequentially hybridized with ${ }^{32} \mathrm{P}$-labeled probes for GST6, IEGT, PR1, and actin genes. C, through E, Comparison of the induction levels of GST6, IEGT and PR-1 genes in wild-type and $\mathrm{nprl}$ plants. Induction levels were calculated as follows. The mRNA level at each timepoint was quantified with a PhosphorImager and was calibrated with the corresponding loading control of actin mRNA. Then, the values from SA-treated samples were divided by the values of their corresponding control samples treated in the absence of SA. Data presented correspond to one representative experiment. This experiment was repeated at least three times and similar induction patterns were detected. 
ment (Fig. 3A, C, and D, white bars). In nprl plants, 2,4-D was also able to activate GST6 and IEGT genes (Fig. 3B, C, and $\mathrm{D}$, gray bars). This activation was maximal at $5 \mathrm{~h}$. In contrast, 2,4-D failed to activate $P R-1$ in either wild-type or $n p r l$ plants (Fig. 3A, B, and E). In sum, these results indicate that NPR 1 is not required for the activation of GST6 and IEGT induced by 2,4-D.

As previously mentioned, a functional SA- and auxin-responsive as-1-like element has been identified in the GST6 promoter (Chen and Singh 1999). We evaluated whether SA increases binding of nuclear factors to the as-1 sequence in $n p r l$ and wild-type Arabidopsis plants. For this purpose, we analyzed the effect of SA on the binding of nuclear proteins to the as-1 sequence of the GST6 promoter, using nuclear extracts obtained from control and SA-treated nprl and wild-type plants. The ability of SA to increase the binding of proteins to the as-1 sequence of the cauliflower mosaic virus (CaMV) 35S promoter was previously demonstrated, using total protein extracts from tobacco and Arabidopsis (Després et al. 2000; Jupin and Chua 1996) and nuclear protein extracts from tobacco (Stange et al. 1997).

For binding experiments, we prepared nuclear extracts from wild-type and nprl Arabidopsis seedlings treated with or without $0.5 \mathrm{mM} \mathrm{SA}$ for $2 \mathrm{~h}$. The $a s$-1-binding activity was detected by gel mobility shift assays, using as a probe a 41 bp DNA fragment of the GST6 promoter that included the as1-like element (GST6-as-1 probe). SA increased the binding of nuclear proteins to the GST6-as-1 probe in wild-type and in nprl plants (Fig. 4). To determine the specific binding, a nonradioactive GST6-as-1 probe was used. Binding was competed for by an excess (18-, 90-, and 180-fold) of this probe but not by equivalent concentrations of a mutated GST6-as-1 probe. The latter had three mutated bases in each of the imperfect TGACGTCA palindromic motifs. These results confirm the specificity of the binding (Fig. 4, lanes 4 to 9 and 13 to 18 ).

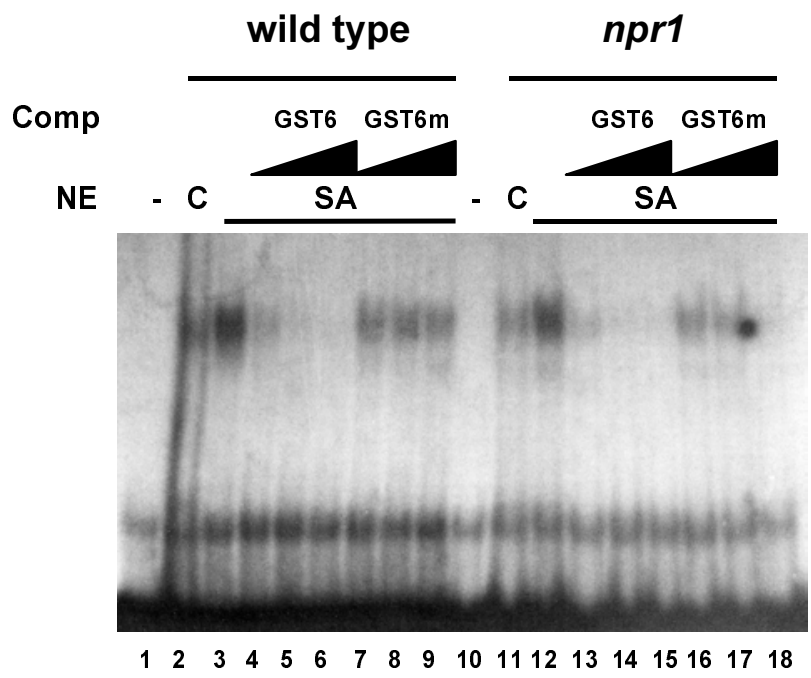

Fig. 4. Salicylic acid (SA)-activated binding of nuclear factors to the GST6 as-1-like promoter element in wild-type and nprl mutant Arabidopsis plants. Gel mobility shift assays were carried out with nuclear extracts obtained from wild-type and $n p r l$ mutant Arabidopsis seedlings treated for $2 \mathrm{~h}$ with $\mathrm{H}_{2} \mathrm{O}(\mathrm{C})$ or with $0.5 \mathrm{mM} \mathrm{SA}(\mathrm{SA})$. A ${ }^{32} \mathrm{P}$-labeled DNA fragment from the GST6 promoter containing an as-1-like element (GST6) was used as probe. Lanes 1 and 10 show control reactions without nuclear extract. Competition experiments were performed with $18 \times$

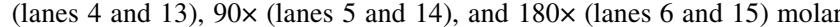
excess of the wild-type probe or $18 \times$ (lanes 7 and 16), 90× (lanes 8 and 17), and 180x (lanes 9 and 18) molar excess of the mutated probe.

\section{DISCUSSION}

Results shown here provide substantial evidence for the existence of differences in the mechanism of activation of late and immediate early genes by SA in Arabidopsis. Unlike the activation of late genes, such as $P R 1$ that proceeds through a NPR1-dependent pathway, the activation of GST6 and IEGTtwo genes characterized here as early genes-does not require NPR1. In addition, late and early genes have different susceptibility to activation by xenobiotics, as shown by the fact that 2,4D activated the expression of GST6 and IEGT but not that of PRl.

In the context of the disease defense response, several recent reports have indicated the existence of a SA-dependent and NPR1-independent pathway that leads to pathogen resistance (Clarke et al. 2000; Kachroo et al. 2000; Rairdan and Delaney 2002; Shah et al. 2001). For example, this pathway has been described in Arabidopsis mutants that have enhanced disease resistance, such as a constitutive expresser of $P R$ genes (cprl, cpr5 and cpr6) (Clarke et al. 2000). Crossing of these mutants with the SA-deficient mutant $e d s 5$ and the SA-degrading transgenic $n a h G$ plants resulted in a dramatic loss of resistance responses, indicating that $\mathrm{SA}$ is required to activate this pathway (Clarke et al. 2000). In contrast, crossing of cpr mutants with the nprl mutant did not affect resistance, indicating that NPR1 is not required (Clarke et al. 2000). Activation of this pathway requires, besides $\mathrm{SA}$, an unknown signal produced by the pathogen and associated with components of the jasmonic acid and ethylene mediated pathways (Clarke et al. 2000; Dong 2001). Considering that SA per se is able to trigger systemic acquired resistance in wild-type plants, but is not able to restore pathogen resistance in the nprl mutant, it has been proposed that this second signal is associated with the local hypersensitive response (Dong 2001). In this context, it would be interesting to evaluate whether immediate early genes activated by SA by an NPR1-independent pathway, such as those described in this paper, could contribute to the SA-dependent and NPR1independent pathway that leads to pathogen resistance.

Findings from this paper have important implications regarding the mechanism by which SA activates defense genes. Current genetic and molecular evidence supports the idea that the NPR1 protein plays an important role in the expression of the late $P R-1$ gene activated by SA through its interaction with TGA factors that recognize $a s-1$-like elements in the $P R-1$ promoter (Dong 2001). Interestingly, TGA factors and as-1-like promoter elements have also been implicated in the SA- and auxin-activated expression of immediate early genes such as tobacco GST1 (Chen and Singh 1999; Droog et al. 1995; Johnson et al. 2001a). Our finding that the NPR1 protein is not required for SA-induced activation of GST6 and IEGT genes adds further support to the idea that the mechanism underlying the activation of immediate early genes is different from the one involved in the activation of late genes, such as $P R-1$. Thus, despite the fact that SA activates early and late genes using a common family of transcription factors and promoter-responsive elements, the activation of these groups of genes proceeds by different mechanisms.

Three different subclasses of TGA factors (I, II, and III), have been described according to their sequence similarities (Niggeweg et al. 2000b; Xiang et al. 1997). Conceivably, the difference in the mechanism of activation of early and late genes could derive from differences in the subclass of TGA factors that recognize the as-1-like elements in early and late genes. This hypothesis is supported by experimental evidence showing that immediate early and late genes are activated by TGA factors belonging to different subclasses. For example, there is evidence for the participation of TGAla (a member of 
subclass I) in the SA- and xenobiotic-induced activation of early genes in tobacco (Johnson et al. 2001b; Pascuzzi et al. 1998). Furthermore, in vivo 2,4-D-inducible binding of TGA1a to the as-1-like element of the tobacco GST1 promoter has recently been demonstrated using chromatin immunoprecipitation assays (Johnson et al. 2001a). On the other hand, evidence suggests that TGA2 (a member of subclass II) is involved in the activation of late genes by SA in Arabidopsis. The use of an in vivo chimera reporter system in Arabidopsis plants showed that DNA binding and transcription mediated by the TGA2 factor is activated by SA but not by 2,4-D or other xenobiotics (Fan and Dong 2002). Interestingly, these effects were not observed in $n p r l$ mutant plants (Fan and Dong 2002).

The idea that different members of the TGA family can be activated by different mechanisms is supported by experiments showing differences in the ability of members of the TGA family to interact with the NPR1 protein. Members of subclass I, such as TGA1a from tobacco (Niggeweg et al. 2000b) and TGA1 or TGA4 from Arabidopsis (Després et al. 2000; Zhou et al. 2000), are unable to bind the NPR1 protein in in vitro protein-protein interaction assays. In contrast, substantial evidence indicates that members of subclass II from tobacco, Arabidopsis, and rice interact strongly with NPR1 in vitro (Chern et al. 2001; Després et al. 2000; Niggeweg et al. 2000b; Zhang et al. 1999; Zhou et al. 2000). Furthermore, in vivo interaction of Arabidopsis TGA2 with NPR1 has been recently reported (Fan and Dong 2002; Subramaniam et al. 2001). The idea that $a s$-1-like elements from immediate early and late genes are targets for different TGA factors is also supported by the occurrence of differences in the relative distances between the two TGACGTCA palindromic cores in the as-1-like element from GST and PR genes (Krawczyk et al. 2002).

It has been shown that the NPR1 protein is required for SAactivated $P R$ genes expression (Cao et al. 1994). Current evidence indicates that the NPR1 protein is involved in the mechanism by which SA activates TGA2 factor (Després et al. 2000; Fan and Dong 2002; Kinkema et al. 2000; Subramaniam et al. 2001). In contrast, our results clearly indicate that NPR 1 is not required for the SA- and 2,4-D-activated expression of the immediate early GST6 and IEGT genes in Arabidopsis. Consistently, we found that NPR1 is not required for the SAactivated binding of endogenous factors to the as-1-like element of the GST6 promoter. We did not demonstrate in this work that TGA factors are part of the protein complex that bound to the GST6-as-1 probe. Nevertheless, above-mentioned evidence from the literature of participation of TGA factors in the SA- and xenobiotic-induced activation of early genes in tobacco (Johnson et al. 2001a and b; Pascuzzi et al. 1998) support this idea. Furthermore, evidence that TGA factors are main components of the as-1-binding activity detected in protein extracts from tobacco and Arabidopsis, such as that used in this work, has also been provided by different groups (Jupin and Chua 1996; Lam and Lam 1995; Niggeweg et al. 2000a and b; Pontier et al. 2002). This evidence and our results are consistent with studies showing that the TGA factors involved in the NPR1-independent pathway do not interact with NPR1. All these studies support the idea that different members of the TGA family can be activated by different mechanisms.

Concerning the regulation of TGA factors of subclass I, the existence of a nuclear $120-\mathrm{kDa}$ protein that interacts with the tobacco TGA1a in a stimulus-reversible way has been reported. It has been suggested that this protein could act as a repressor of gene expression (Johnson et al. 2001b). How SA or other stimuli can overcome this repression in order to trigger the expression of early genes is still not known. Evidence from our laboratory and other groups points to the involvement of redox signals and protein phosphorylation events in the activa- tion of TGA factors (Garretón et al. 2002; Hidalgo et al. 2001; Jupin and Chua 1996; Stange et al. 1997). Further studies aimed at identifying the possible targets of phosphorylation and redox modification will allow a better understanding of the mechanisms involved in this pathway.

Although GST6 and IEGT genes were found to behave as immediate early genes in response to SA, they differed in their response to CHX (Fig. 2C and D). Differences in behavior of early response genes to SA and CHX have been previously described in tobacco by Horvath and associates (1998). These authors classified genes into four groups, based on their mechanisms for the regulation of steady state levels of mRNAs. According to this classification, Arabidopsis IEGT belongs to class I, but GST6 does not fit into any of the four classes described. With regard to the difference in response to $\mathrm{CHX}$, different mechanisms of regulation have been invoked (Horvath et al. 1998). A sustained increase in mRNA levels in response to $\mathrm{CHX}$, such as seen for IEGT, can be explained by the requirement of a labile protein for a negative regulation, either at the level of transcription or mRNA stability. A transient increase in mRNA levels, such as that detected for GST6, can be due to a direct effect of $\mathrm{CHX}$ on the signaling pathway. Interestingly, a recent report demonstrates that the levels of different TGA factors and their relative contribution into the protein complexes that bind $a s-1$ sequence can be regulated by proteolysis during development in Arabidopsis (Pontier et al. 2002). It would be interesting to determine if a mechanism of this kind may contribute to regulation of the transcriptional activity by TGA factors during defense and, thus, explain the effect of CHX.

Using nuclear extracts of wild-type and nprl Arabidopsis plants, we found that SA potentiated the binding of endogenous factors to the SA- and auxin-responsive as-1-like element of the GST6 promoter. The same experimental system has been previously used to study the effect of SA in tobacco (Jupin and Chua 1996; Stange et al. 1997) and Arabidopsis (Després et al. 2000). However, using total extracts from nprl plants, Després and associates (2000) were unable to demonstrate SA-induced changes in the binding of endogenous TGA factors to the CaMV 35S as- 1 element. Based on this finding, the authors concluded that the DNA-binding enhancement of TGA factors induced by SA depends on the presence of NPR1 protein (Després et al. 2000). Although we do not know the reason for this discrepancy, it may relate to the differences in the probes (CaMV 35S as- 1 vs. GST6 as-1) and preparations used (total vs. nuclear extracts).

Another aspect that must be considered in the future to understand the involvement of a common family of promoterresponsive elements in the activation of early and late genes, is the interaction of as-1-like elements with other promoter elements. In this context, it has been proposed that the $\mathrm{W}$ box, which binds factors from the WRKY family, could act as a SAresponsive element in the activation of late PR genes (Maleck et al. 2000). This is based on the fact that $\mathrm{W}$ boxes are present in the promoters of 31 genes that are coexpressed with the $P R$ 1 gene in SA-treated Arabidopsis plants, as shown by analysis of data from cDNA microarray experiments (Maleck et al. 2000). We are currently evaluating the presence of other putative SA-responsive elements in immediate early genes coexpressed with GST6 in SA-treated Arabidopsis, to assess possible interactions of $a s-1$ with other elements in these promoters.

\section{MATERIALS AND METHODS}

\section{Plant material and growth conditions.}

Arabidopsis thaliana ecotype Columbia was used as the wild type in this study. The nprl-1 mutant was obtained from $\mathrm{X}$. 
Dong (Duke University) (Cao et al. 1994). Seeds were sterilized in a $50 \%$ hypochlorite solution for $7 \mathrm{~min}$, were washed three times with water, and were germinated on MurashigeSkoog (MS) medium containing $15 \mathrm{~g}$ of sucrose per liter. Seedlings were grown in vitro for 15 days in a growth chamber (22 $\pm 2^{\circ} \mathrm{C}, 16$ h light).

\section{Treatment of plants with SA, 2,4-D, and CHX.}

Arabidopsis seedlings (15 days old), maintained in darkness during the last $12 \mathrm{~h}$ previous to the assay, were used in all experiments. To assay gene expression by Northern blot, 50 seedlings were used for each treatment. To assay the as-1-binding activity, 100 to 150 seedlings were used for each treatment. Seedlings were carefully taken out from the MS medium and were placed, root side down, in a petri dish containing $25 \mathrm{ml}$ of a $0.5-\mathrm{mM}$ SA or a 100- $\mu$ M 2,4-D solution. Stock solutions of SA (Sigma, St Louis or Riedel-deHaën, Seelze, Germany) and 2,4-D (Sigma) were fresh-prepared in $\mathrm{H}_{2} \mathrm{O}$ and dimethyl sulfoxide (DMSO), respectively. Final concentration of DMSO in the medium was $0.5 \%$ (vol/vol). Control samples were incubated in water for SA treatments or in $0.5 \% \mathrm{vol} / \mathrm{vol} \mathrm{DMSO}$ for 2,4-D treatments. Treatments were carried out in a growth chamber under constant temperature $\left(22\right.$ to $\left.25^{\circ} \mathrm{C}\right)$ and light. To test the effect of $\mathrm{CHX}$, seedlings were first incubated for $1 \mathrm{~h}$ in a solution of $20 \mu \mathrm{g}$ of CHX per ml or in water as a control, and then, were treated for 2 or $24 \mathrm{~h}$ in the absence or in the presence of $0.5 \mathrm{mM}$ SA. Stock solution of $10 \mathrm{mg}$ of $\mathrm{CHX}$ per $\mathrm{ml}$ (Sigma) was fresh-prepared in water. Immediately after treatments, seedlings were frozen in liquid nitrogen and were stored at $-70^{\circ} \mathrm{C}$.

\section{RNA extraction and Northern analysis.}

Total RNA was extracted from frozen plant tissue samples using the TRIzol reagent (Invitrogen, Carlsbad, CA, U.S.A.), according to the manufacturer's protocol. Samples containing $20 \mu \mathrm{g}$ of RNA were separated on formaldehyde-agarose gels. After transfer of RNA onto nylon membranes (Hybond N; Amersham Biosciences, Corp. Piscataway, NJ, U.S.A.), filters were hybridized with the ${ }^{32} \mathrm{P}$-labeled probe (about $50 \times 10^{6}$ counts per minute [cpm]). For GST6, hybridization was carried out at $55^{\circ} \mathrm{C}$, as described by Zhang and associates (1993). For $P R 1, I E G T$, and $18 \mathrm{~S}$ rRNA, hybridization was performed at $42^{\circ} \mathrm{C}$ in a buffer containing $6 \times \mathrm{SSC}(1 \times \mathrm{SSC}$ is $0.15 \mathrm{M} \mathrm{NaCl}$ plus $0.015 \mathrm{M}$ sodium citrate), $5 \times$ Denhardt's solution, $50 \%$ formamide, $0.5 \%$ sodium dodecyl sulfate (SDS), $1 \mathrm{mM}$ EDTA, and $150 \mu \mathrm{g}$ of salmon sperm carrier DNA per ml. For the actin gene, hybridization was performed as for PRl, IEGT, and $18 \mathrm{~S}$ rRNA, except $40 \%$ formamide was used. Then, filters were washed at $42^{\circ} \mathrm{C}$ in $2 \times \mathrm{SSC}, 0.1 \% \mathrm{SDS}$ for $10 \mathrm{~min}$ and twice at 55 to $60^{\circ} \mathrm{C}$ in $0.2 \times \mathrm{SSC}, 0.1 \% \mathrm{SDS}$ for $10 \mathrm{~min}(G S T 6, P R l), 7$ min (IEGT), 30 min (actin), or 90 min (18S rRNA).

Polymerase chain reaction (PCR)-amplified DNA fragments of 557 and $420 \mathrm{bp}$ for Arabidopsis GST6 and PRI genes, respectively, were obtained using previously described synthetic primers (Chen et al. 1996; Ho and Yang 1999). As a probe for Arabidopsis IEGT, a 360-bp DNA fragment was obtained by PCR, using as a template the expressed sequence tag (EST) ATTS 3278 and the $5^{\prime}$ and $3^{\prime}$ primers 5' GTGATCATCATCATCGAAAGC 3' and 5' GGA GTTTCTCAAGCTGGTC 3', respectively. For the Arabidopsis actin gene, a 700-bp DNA fragment, obtained by PCR using the $5^{\prime}$ and $3^{\prime}$ primers $5^{\prime}$ GCTATGTATGTCGCCATTCAAGC $3^{\prime}$ and 5'-CATCATATTCTGCCTTTGC(A/G)ATCC 3', respectively, was used as a probe. For the 18S rRNA gene, a 1,100-bp DNA fragment was obtained by PCR using the EST H8B10T7 cloned in pBluescript $\mathrm{SK}^{-}$as a template and the primers T7 and RP. The amplified fragments were sequenced and labeled by PCR, except
18S rRNA probe, which was labeled by random priming using [ $\alpha-32 P]$ dCTP (RTS-RadPrime; Life Technologies, Gaithersburg, MD, U.S.A.).

\section{Nuclear extracts and gel mobility shift assays.}

Nuclear extracts were prepared from Arabidopsis seedlings according to the procedure described by Green and associates (1989), modified as follows. Frozen seedlings (4 $\mathrm{g}$ fresh weight) were ground in a mortar with liquid nitrogen and were resuspended in $30 \mathrm{ml}$ of homogenization buffer $(1 \mathrm{M}$ hexylene glycol, $10 \mathrm{mM}$ PIPES/KOH, pH 7.0, $10 \mathrm{mM}$ $\mathrm{MgCl}_{2}, 10 \mathrm{mM} \mathrm{NaF}, 10 \mathrm{mM} \mathrm{KCl}, 1 \mathrm{mM}$ EDTA, $0.5 \%$ vol/vol Triton X-100, $1 \mathrm{mM}$ 2-mercaptoethanol, $0.8 \mathrm{mM}$ phenylmethylsulfonyl fluoride [PMSF]). The homogenate was filtered through two layers of nylon and one of Miracloth, and chloroplasts were lysed by addition of $1 / 20$ volume of NIB-T buffer (10 mM Tris-HCl, pH 9.5, $10 \mathrm{mM}$ EDTA, $100 \mathrm{mM} \mathrm{KCl}, 0.5 \mathrm{M}$ sucrose, $10 \%$ vol/vol Triton X-100, 4 $\mathrm{mM}$ spermidine, $1 \mathrm{mM}$ spermine, $1 \mathrm{mM}$ 2-mercaptoethanol) (Bouchez and Camilleri 1998). Then, the nuclei were sedimented at $2,000 \times g$ for $10 \mathrm{~min}$ at $4{ }^{\circ} \mathrm{C}$, using polypropylene tubes to improve pellet recovering. The pellet was then washed twice with $10 \mathrm{ml}$ of nuclei wash buffer $(0.5 \mathrm{M}$ hexylene glycol, $10 \mathrm{mM}$ PIPES/KOH, pH 7.0, $10 \mathrm{mM} \mathrm{MgCl}_{2}, 10$ $\mathrm{mM} \mathrm{NaF}, 10 \mathrm{mM} \mathrm{KCl}, 1 \mathrm{mM}$ EDTA, $1 \mathrm{mM}$ 2-mercaptoethanol, $0.8 \mathrm{mM}$ PMSF). Then, the nuclei were sedimented again at $2,000 \times g$ for $10 \mathrm{~min}$ at $4^{\circ} \mathrm{C}$. The nuclear pellet was resuspended in $400 \mu \mathrm{l}$ of lysis buffer $(15 \mathrm{mM} \mathrm{HEPES/KOH}, \mathrm{pH}$ $7.5,110 \mathrm{mM} \mathrm{KCl}, 5 \mathrm{mM} \mathrm{MgCl}_{2}, 10 \mathrm{mM} \mathrm{NaF}, 0.5 \mathrm{mM}$ EDTA, $2 \mu \mathrm{g}$ of leupeptin per $\mathrm{ml}, 1 \mathrm{mM}$ benzamidine). After 1 $\mathrm{h}$ at $4^{\circ} \mathrm{C}$, ammonium sulfate was added, and fractionation was performed as described (Green et al. 1989). After the second fractionation, the pellet was resuspended in $40 \mu \mathrm{l}$ of nuclear extract buffer (25 mM HEPES/KOH, pH 7.5, $50 \mathrm{mM}$ $\mathrm{NaCl}, 0.1 \mathrm{mM}$ EDTA, $10 \%$ [vol/vol] glycerol, $10 \mathrm{mM} \mathrm{NaF}, 2$ $\mu \mathrm{g}$ of leupeptin per $\mathrm{ml}, 1 \mathrm{mM}$ benzamidine), was incubated for $10 \mathrm{~min}$ at $4^{\circ} \mathrm{C}$, and was dialyzed against the same buffer overnight at $4^{\circ} \mathrm{C}$, and was stored at $-70^{\circ} \mathrm{C}$. Protein concentration was determined using the BioRad kit (Bio-Rad, Hercules, CA, U.S.A.). The final yield was 60 to $90 \mu \mathrm{g}$ of nuclear protein per gram of fresh leaf tissue weight.

DNA protein binding assays were carried out with nuclear protein extracts (5 to $20 \mu \mathrm{g}$ of protein), incubated with the ${ }^{32} \mathrm{P}$ labeled probe $(25,000 \mathrm{cpm}, 0.031 \mathrm{pmol})$ in $20 \mu \mathrm{l}$ of binding buffer (50 mM HEPES, pH 7.9, $130 \mathrm{mM} \mathrm{NaCl}, 2 \mathrm{mM} \mathrm{MgCl}$, $9.5 \mathrm{mM}$ dithiothreitol, 4\% [vol/vol] glycerol and $15 \mathrm{ng}$ of poly (dG)·poly(dC) [Amersham Pharmacia Biotech, Piscataway, NJ, U.S.A.]) for $5 \mathrm{~min}$ at room temperature. For competition experiments, the indicated molar excess of the nonradioactive probe was included in the binding assay 5 min before addition of the labeled probe. DNA protein complexes were separated from the unbound probe by electrophoresis in a $5 \%$ polyacrylamide gel in Tris-borate-EDTA buffer. Following electrophoresis, gels were dried and subjected to autoradiography at $-70^{\circ} \mathrm{C}$ for $10 \mathrm{~h}$. To obtain the GST6 as-1 probe, the following oligonucleotide was used: 5'-GCTTCTCAGAGGAGGTCGTCAT CAATGACATAAGTTCTAG-3' (protein binding motifs are indicated in bold). The complementary strand was synthesized using the primer $5^{\prime}$-GAGAAGC-3', dNTPs, $\left(\alpha-{ }^{32} \mathrm{P}\right) \mathrm{dCTP}$, and Klenow DNA polymerase, following standard protocols (Ausubel et al. 1997). For competition, nonradioactive GST6 as-1 probe was obtained using the oligonucleotide 5'GCTTCTCAGAGGAGGTCGTCATCAATGACATAAGAT TCTAG -3' annealed to 5'-CTAGAATCTTATGTCATTGA TGACGACCTCCTCTGAGAAGC-3', and a mutated GST6 as- 1 probe was prepared using the oligonucleotide 5'GCTTCTCAGAGGAGGTCAGCGTCAACGCTATAAGAT 
TCTAG-3' annealed to 5'- CTAGAATCTTATAGCGTTGAC GCTGACCTCCTCTGAGAAGC-3' (mutated nucleotides are underlined).

\section{ACKNOWLEDGMENTS}

The authors are greatly indebted to X. Dong (Department of Biology, Duke University, Durham, NC, U.S.A.) for providing the nprl-1 mutant We thank M. Bitran and Al. Minniti for improving the manuscript. This work was supported by research grant 1020593 from Fondecyt-Conicyt, Chile.

\section{LITERATURE CITED}

Alvarez, M. E. 2000. Salicylic acid in the machinery of hypersensitive cell death and disease resistance. Plant. Mol. Biol. 44:429-442.

Alvarez, M. E., Pennell, R. I., Meijer, P.-J., Ishikawa, A., Dixon, R. A., and Lamb, C. 1998. Reactive oxygen intermediates mediate a systemic signal network in the establishment of plant immunity. Cell 92:773784

Ausubel, F. M. 1997. Current Protocols in Molecular Biology. John Wiley and Sons, New York.

Borsani, O., Valpuesta V., and Botella, M. A. 2001. Evidence for a role of salicylic acid in the oxidative damage generated by $\mathrm{NaCl}$ and osmotic stress in Arabidopsis seedlings. Plant Physiol. 126:1024-1030.

Bouchez, D., and Camilleri, C. 1998. High molecular weight DNA extraction from Arabidopsis. Pages 61-70 in: Methods in Molecular Biology, Vol. 82: Arabidopsis Protocols. J. M. Martínez-Zapater and J. Salinas, eds. Humana Press, Totowa, NJ, U.S.A.

Cao, H., Bowling, S. A., Gordon, A. S., and Dong, X. 1994. Characterization of an Arabidopsis mutant that is nonresponsive to inducers of systemic acquired resistance. Plant Cell 6:1583-1592.

Cao, H., Glazebrook, J., Clarke, J. D., Volko, S., and Dong, X. 1997. The Arabidopsis NPR1 gene that controls systemic acquired resistance encodes a novel protein containing ankyrin repeats. Cell 88:57-63.

Chen, W., and Singh, K. B. 1999. The auxin, hydrogen peroxide and salicylic acid induced expression of the Arabidopsis GST6 promoter is mediated in part by an ocs element. Plant J. 19:667-677.

Chen, W., Chao, G., and Singh, K.B. 1996. The promoter of a $\mathrm{H}_{2} \mathrm{O}_{2}$ inducible, Arabidopsis glutathione $S$-transferase gene contains closely linked OBF- and OBP1-binding sites. Plant J. 10:955-966.

Chern, M. S., Fitzgerald, H. A., Yadav, R. C., Canlas, P. E., Dong, X., and Ronald, P. 2001. Evidence for a disease-resistance pathway in rice similar to NPR1-mediated signaling pathway in Arabidopsis. Plant J. 27:101-113.

Clarke, J. D., Volko, S. M., Ledford, H., Ausubel, F. M., and Dong, X. 2000. Roles of salicylic acid, jasmonic acid, and ethylene in cpr-induced resistance in Arabidopsis. Plant Cell 12:2175-2190.

Delaney, T. P., Uknes, S., Vernooij, B., Friedrich, L., Weymann, K. Negrotto, D., Gaffney, T., Gut-Rella, M., Kessmann, H., Ward, E., and Ryals, J. 1994. A central role of salicylic acid in plant disease resistance. Science 266:1247-1250.

Després, C., DeLong, C., Glaze, S., Liu, E., and Fobert, P. R. 2000. The Arabidopsis NPR1/NIM1 protein enhances the DNA binding activity of a subgroup of the TGA family of bZIP transcription factors. Plant Cell 12:279-290

Dong, X. 2001. Genetic dissection of systemic acquired resistance. Curr. Opin. Plant Biol. 4:309-314.

Droog, F., Spek, A., van der Kooy, A., de Ruyter, A., Hoge, H., Libbenga, K., Hooykaas, P., and van der Zaal, B. 1995. Promoter analysis of the auxin-regulated tobacco glutathione $S$-transferase genes Nt103-1 and Nt103-35. Plant. Mol. Biol. 29:413-429.

Edwards, R., Dixon, D. P., and Walbot, V. 2000. Plant glutathione Stransferases: Enzymes with multiple functions in sickness and in health. Trends Plant Sci. 5:193-198.

Fan, W., and Dong, X. 2002. In vivo interaction between NPR1 and transcription factor TGA2 leads to salicylic acid-mediated gene activation in Arabidopsis. Plant Cell 14:1377-1389.

Garretón, V., Carpinelli, J., Jordana, X., and Holuigue, L. 2002. The as-1 promoter element is an oxidative stress-responsive element and salicylic acid activates it via oxidative signals. Plant Physiol. 130:15161526.

Green, P. J., Kay, S. A., Lam, E., and Chua, N.-H. 1989. In vitro footprinting. Pages B11:1-B11:22 in: Plant Molecular Biology Manual. S. B. Gelvin and R.A. Schilperoort, eds. Kluwer Academic Publishers, Dordrecht, The Netherlands.

Hidalgo, P., Garretón, V., Berríos, C. G., Ojeda, H., Jordana, X., and Holuigue, L. 2001. A nuclear casein kinase 2 activity is involved in early events of transcriptional activation induced by salicylic acid in tobacco. Plant Physiol. 125:396-405.

Ho, G.-D., and Yang, C.-H. 1999. A single locus leads to resistance of Arabidopsis thaliana to bacterial wilt caused by Ralstonia solanacearum through a hypersensitive-like response. Phytopathology 89:673-678.

Horvath, D., and Chua, N.-H. 1996. Identification of an immediate-early salicylic acid-inducible tobacco gene and characterization of induction by other compounds. Plant. Mol. Biol. 31:1061-1072.

Horvath, D. M., Huang, D. J., and Chua, N.-H. 1998. Four classes of salicylate-induced tobacco genes. Mol. Plant-Microbe Interact. 11:895-905.

Johnson, C., Boden, E., Desai, M., Pascuzzi, P., and Arias, J. 2001a. In vivo target promoter-binding activities of a xenobiotic stress-activated TGA factor. Plant J. 28:237:243

Johnson, C., Glover, G., and Arias, J. 2001b. Regulation of DNA binding and trans-activation by a xenobiotic stress-activated plant transcription factor. J. Biol. Chem. 276:172-178.

Jupin, I., and Chua, N.-H. 1996. Activation of the CaMV as-1 cis-element by salicylic acid: Differential DNA-binding of a factor related to TGA1a. EMBO (Eur. Mol. Biol. Organ.) J. 15:5679-5689.

Kachroo, P., Yoshioka, K., Shah, J., Dooner, H. K., and Klessig, D. F. 2000. Resistance to Turnip crinkle virus in Arabidopsis is regulated by two host genes and is salicylic acid dependent but NPR1, ethylene, and jasmonate independent. Plant Cell 12:677-690.

Kinkema, M., Fan, W., and Dong, X. 2000. Nuclear localization of NPR1 is required for activation of $P R$ gene expression. Plant Cell 12:23392350

Krawczyk, S., Thurow, C., Niggeweg, R., and Gatz, C. 2002. Analysis of the spacing between the two palindromes of activation sequence-1 with respect to binding to different TGA factors and transcriptional activation potential. Nucleic Acids Res. 30:775-781.

Lam, E., and Lam, Y. K. P. 1995. Binding site requirements and differential representation of TGA factors in nuclear ASF-1 activity. Nucleic Acids Res. 23:3778-3785.

Lebel, E., Heifetz, P., Thorne, L., Uknes, S., Ryals, J., and Ward, E. 1998. Functional analysis of regulatory sequences controlling $P R-1$ gene expression in Arabidopsis. Plant J. 16:223-233.

Levine, A., Tenhaken, R., Dixon, R., and Lamb, C. 1994. $\mathrm{H}_{2} \mathrm{O}_{2}$ from the oxidative burst orchestrates the plant hypersensitive disease resistance response. Cell 79:583-593

Li, Y., Baldauf, S., Lim, E. K., and Bowles, D. J. 2001. Phylogenetic analysis of the UDP-glycosyltransferase multigene family of Arabidopsis thaliana. J. Biol. Chem. 276:4338-4343.

Lim, E. K., Doucet, C. J., Li, Y., Elias, L., Worrall, D., Spencer, S. P., Ross, J., and Bowles, D. J. 2002. The activity of Arabidopsis glycosyltransferases toward salicylic acid, 4-hydroxybenzoic acid, and other benzoates. J. Biol. Chem. 277:586-592.

Maleck, K., Levine, A., Eulgem, T., Morgan, A., Schmid, J., Lawton, K. A., Dangl, J. L., and Dietrich, R. A. 2000. The transcriptome of Arabidopsis thaliana during systemic acquired resistance. Nat. Genet. 26:403-410.

Marrs, K. A. 1996. The functions and regulation of glutathione $S$-transferases in plants. Annu. Rev. Plant Physiol. Plant Mol. Biol. 47:127-158.

Niggeweg, R., Thurow, C., Kegler, C., and Gatz, C. 2000a. Tobacco transcription factor TGA2.2 is the main component of ASF1/SARP and is involved in salicylic acid- and auxin-inducible expression of as-1-containing target promoters. J. Biol. Chem. 275:19897-19905.

Niggeweg, R., Thurow, C., Weigel, R., Pfitzner, U., and Gatz, C. 2000b. Tobacco TGA factors differ with respect to interaction with NPR1, activation potential and DNA-binding properties. Plant Mol. Biol. 42:775-788.

Pascuzzi, P., Hamilton, D., Bodily, K., and Arias, J. 1998. Auxin-induced stress potentiates trans-activation by a conserved plant basic/leucinezipper factor. J. Biol. Chem. 273:26631-26637.

Pontier, D., Miao, Z. H., and Lam, E. 2001. Trans-dominant suppression of plant TGA factors reveals their negative and positive roles in plant defense responses. Plant J. 27:529-538.

Pontier, D., Privat, I., Trifa Y., Zhou, J. M., Klessig, D. F., and Lam, E. 2002. Differential regulation of TGA transcription factors by post-transcriptional control. Plant J. 32, 641-653.

Qin, X. F., Holuigue, L., Horvath, D. M., and Chua, N.-H. 1994. Immediate early transcription activation by salicylic acid via the cauliflower mosaic virus as-1 element. Plant Cell 6:863-874

Rairdan, G. J. and Delaney, T. P. 2002. Role of salicylic acid and NIM1/PR1 in race-specific resistance in Arabidopsis. Genetics 161:803-811.

Rao, M. V., and Davis, K. R. 1999. Ozone-induced cell death occurs via two distinct mechanisms in Arabidopsis: The role of salicylic acid Plant J. 17:603-614.

Ryals, J., Weymann, K., Lawton, K., Friedrich, L., Ellis, D., Steiner, H. Y., Johnson, J., Delaney, T. P., Jesse, T., Vos, P., and Uknes, S. 1997. 
The Arabidopsis NIM1 protein shows homology to the mammalian transcription factor inhibitor IкB. Plant Cell 9:425-439.

Schenk, P. M., Kazan, K., Wilson, I., Anderson, J. P., Richmond, T., Somerville, S. C., and Manners, J. M. 2000. Coordinated plant defense responses in revealed by microarray analysis. Proc. Natl. Acad. Sci. U.S.A. 97:11655-11660.

Shah, J., Kachroo, P., Nandi, A., and Klessig, D. F. 2001. A recessive mutation in the Arabidopsis SSI2 gene confers SA- and NPRI-independent expression of $P R$ genes and resistance against bacterial and oomycete pathogens. Plant Cell 25:563-574.

Stange, C., Ramírez, I., Gómez, I., Jordana, X., and Holuigue, L. 1997. Phosphorylation of nuclear proteins directs binding to salicylic acidresponsive elements. Plant J. 11:1315-1324.

Strompen, G., Grüner, R., and Pfitzner, U. M. 1998. An as-1-like motif controls the level of expression of the gene for the pathogenesisrelated protein 1A from tobacco. Plant Mol. Biol. 37:871-883.

Subramaniam, R., Desveaux, D., Spickler, C., Michnick, S. W., and Brisson, N. 2001. Direct visualization of protein interactions in plant cells. Nature Biotech. 19:769-772.

Uknes, S., Dincher, S., Friedrich, L., Negrotto, D., Williams, S., ThompsonTaylor, H., Potter, S., Ward, E., and Ryals, J. 1993. Regulation of pathogenesis-related protein-1a gene expression in tobacco. Plant Cell 5:159-169.
Ulmasov, Y., Hagen, G., and Guilfoyle, T. 1994. The ocs element in the soybean $\mathrm{GH} 2 / 4$ promoter is activated by both active and inactive auxin and salicylic acid analogues. Plant Mol. Biol. 26:1055-1064.

Van Loon, L. C., and Van Strien, E. A. 1999. The families of pathogenesis-related proteins, their activities, and comparative analysis of PR-1 type proteins. Physiol. Mol. Plant Pathol. 55:85-97.

Xiang, C., Miao, Z. H., and Lam, E. 1996. Coordinated activation of as-1 type elements and a tobacco glutathione $S$-transferase gene by auxins, salicylic acid, methyl-jasmonate and hydrogen peroxide. Plant Mol. Biol. 32:415-426.

Xiang, C., Miao, Z. H., and Lam, E. 1997. DNA-binding properties, genomic organization and expression pattern of TGA6, a new member of the TGA family of bZIP transcription factors in Arabidopsis thaliana. Plant Mol. Biol. 34:403-415.

Zhang, Y., Fan, W., Kinkema, M., Li, X., and Dong, X. 1999. Interaction of NPR1 with basic leucine zipper protein transcription factors that bind sequences required for salicylic acid induction of the $P R-1$ gene. Proc. Natl. Acad. Sci. U.S.A. 96:6523-6528.

Zhou, J.-M., Trifa, Y., Silva, H., Pontier, D., Lam, E., Shah, J., and Klessig, D. F. 2000. NPR1 differentially interacts with members of the TGA/OBF family of transcription factors that bind an element of the $P R-1$ gene required for induction by salicylic acid. Mol. Plant-Microbe Interact. 13:191-202. 